\title{
Jezikoslovno nazivlje u Frinihovu djelu Izbor atičkih glagola $i$ imenica
}

\author{
Petra Matović ${ }^{(0)}$ \\ Filozofski fakultet Sveučilišta u Zagrebu \\ pmatovic@ffzg.hr \\ Beata Kovačević \\ Filozofski fakultet Sveučilišta u Zagrebu \\ beabeica94@gmail.com
}

SAŽETAK: U radu se analizira antičko jezikoslovno nazivlje u Frinihovu djelu Izbor atičkih glagola i imenica, antičkom jezičnom savjetniku pisanom u duhu aticizma. Nazivlje je podijeljeno prema razinama jezičnoga opisa (fonološko, morfološko, sintaktičko i semantičko). Unutar svake od četiriju skupina nazivlje se dalje analizira prema učestalosti, jezičnim pojavama koje opisuje i vrstama riječi te se pokušavaju utvrditi izvori iz kojih je nazivlje preuzeto.

Ključne riječi: Frinih; grčka leksikografija; aticizam; antički gramatičari

\section{Uvod}

Grčki leksikograf Frinih (II. st.) autor je djela Izbor atičkih glagola i imenica (u daljnjem tekstu: Izbor), koje možemo smatrati jednim od najranijih jezičnih savjetnika. ${ }^{1}$ Frinihove se purističke opaske smatraju vrijednom jezikoslovnom građom jer svjedoče o promjenama u grčkome jeziku helenističkoga i rimskoga doba. ${ }^{2}$ Tipični Frinihov savjet glasi: »nemoj se koristiti riječju $\mathrm{A}$, nego $\mathrm{B} \ll$, pri čemu je riječ $\mathrm{A}$ primjer jezične prakse njegovih suvremenika, a $\mathrm{B}$ obično nalazimo kod nekoga klasičnog autora. Budući da je Izbor samo popis rječničkih natuknica, razmjerno je malo autorskoga teksta za analizu. Ipak, budući da je antičko grčko gramatičko nazivlje u Frini-

\footnotetext{
(1) https://orcid.org/0000-0003-2502-7704 [Petra Matović]

1 Imena antičkih pisaca i naslovi djela te godine rođenja i smrti navode se prema Leksikonu antičkih autora (Škiljan 1996), osim ako nije drukčije navedeno.

2 Browning opaske gramatičara općenito smatra jednim od pet najvažnijih izvora za poznavanje helenističke koine (Browning 1983: 22), a posebno se bavi Frinihom, kojega uspoređuje s jezikom Novoga zavjeta (ibid. 47-48). Za njega naziv grammarian uključuje i leksikografe (isto tako Lee 2013). Više o mišljenju suvremenih autora o Frinihu u 4.1.
} 
hovo doba već bilo razvijeno, može se govoriti o uporabi znanstvenoga nazivlja u Izboru. Valja napomenuti i da se, iako je riječ o razdoblju prije razvoja jezikoslovlja kao znanosti, nazivlje koje su stvorili stari Grci i danas upotrebljava u novogrčkome, a u latinskoj inačici, posredovano djelovanjem Rimljana, ušlo je u gramatičku tradiciju Zapada.

\section{Aticizam, antički purizam}

Važno je razlikovati dva značenja u kojima se riječ aticizam (grč. $\dot{\alpha} \tau \tau \imath \varkappa \imath \sigma \mu o ́ s) ~ u p o t r e b-$ ljava: jedno pripada retorici, a drugo jezikoslovlju. U retorici aticizam označava stil koji je nastao u II. st. pr. Kr. kao reakcija na azijanizam, govornički stil koji se odlikovao kićenim izražavanjem i obiljem retoričkih ukrasa. Aticisti su stilskim uzorima proglasili autore klasičnoga doba grčke književnosti, koji su bili poznati po jezgrovitome i jednostavnome načinu izražavanja: povjesničara Tukidida, filozofa Platona, govornike Lisiju i Demostena i dr.

Drugo značenje pojma aticizam označava težnju da se oživi govor klasičnoga doba. Klasično doba grčke kulture često je sinonim za tzv. zlatno doba Atene, pa se u skladu s time najprestižnijom jezičnom inačicom smatrala ona koja se tada u Ateni govorila: atički dijalekt. Aticizam je u ovome kontekstu reakcija na jezične promjene, tj. nastanak helenističke koine, općega jezika kojim se koristilo na području Aleksandrove države. ${ }^{3}$ Iako je koine nastala na temelju atičkoga dijalekta, postoje značajne razlike u odnosu na njega (koine je fonološki bliža novogrčkomu nego klasičnomu grčkomu; morfološki se sustav reorganizira te nestaju dvojina, medij, optativ i dativ, a nepravilne se paradigme ujednačavaju ili nestaju). ${ }^{4}$ Da bi govornici lakše prevladali jaz između govorne koine i atičkoga koji se smatrao jezičnim idealom, nastaju brojni priručnici u kojima se objašnjava kako »pravilno« govoriti grčki, po uzoru na kanonske govonike poput već spomenutog Demostena i autore stare komedije poput Aristofana. Jedan je od takvih priručnika i Frinihov Izbor, o kojemu je riječ u ovome radu. Aticizam je bio na vrhuncu od kraja I. st. do početka III. st. (Kazazis 2007: 1200), no smatra se da je imao dalekosežne posljedice u razvoju grčkoga jezika i utjecaj na diglosiju u XX. st.

3 Osnovna podjela prema $H E$ »aticizam « i Strobel (2009), o jezičnom aticizmu više donose Browning (1983: 44-50), Andriōtēs (1995: 57-66), Swain (1996. passim), Kazazis (2007), Strobel (2009), Horrocks (2010: 133-141). O povijesnom kontekstu u kojem nastaje koine v. Missiou (2007).

$4 H E$ »koine« i »Grci«. Detaljnije o koine Browning (1983: 19-52), Andriōtēs (1995: 33-70), Horrocks (2010: 79-188). Teoretski pristup opisuje Bubenik (2007). 


\section{Jezikoslovna tradicija stare Grčke}

\subsection{Razvoj grčkoga jezikoslovlja i jezikoslovnoga nazivlja}

Stari Grci bili su »ne samo osnivači principa klasične evropske gramatike nego i zaslužni za tradiciju gramatičkog proučavanja u kasnijim vekovima« (Ivić 2001: 19). ${ }^{5}$ Jezičnim pitanjima u staroj Grčkoj prvi su se bavili filozofi. ${ }^{6}$ Sofist Protagora bavio se kategorijom roda i zavisnim rečenicama, a njegov mlađi suvremenik Platon u dijalogu Kratil raspravljao je o arbitrarnosti jezičnoga znaka. Platonov učenik Aristotel smatrao je da nema nikakve povezanosti između riječi i pojma koji označava, dok su stoici vjerovali da takva povezanost postoji i da je potpuno prirodna. Stoici su unutar

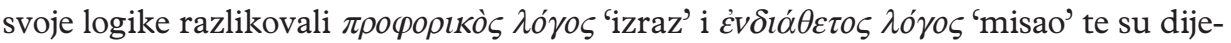
lili logiku na dvije grane (

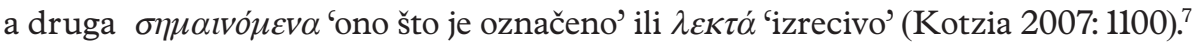

Uz rasprave o značenju, filozofi su dali doprinos razvoju gramatičkoga naziv-

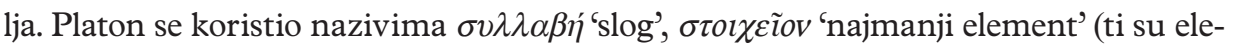

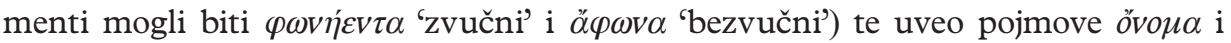
$\tilde{\rho} \tilde{\eta} \mu \alpha$, koji su označavali imenski i glagolski dio rečenice. Aristotel je tomu dodao kategoriju koju je nazvao $\sigma v ́ v \delta \varepsilon \sigma \mu o \imath$ 'veznici', a koja je uključivala riječi koje služe logičkomu povezivanju: veznike, zamjenice, član i vjerojatno prijedloge. Uveo je i naziv $\pi \tau \tilde{\omega} \sigma \iota \varsigma$, koji je za njega značio bilo kakvo odstupanje od osnovnoga oblika riječi: kod glagolskih oblika odstupanje od prezenta, kod pridjeva komparativ. U Poetici nabraja $\mu \varepsilon \dot{\varepsilon} \eta \tau \tilde{\eta} \varsigma \lambda \varepsilon^{\prime} \xi \varepsilon \omega \varsigma$ 'dijelove govora', koji će kasnije postati 'vrste riječi'. Međutim, ni Platon ni Aristotel nisu se sustavno bavili gramatičkim nazivljem. Od filozofskih škola ključan doprinos razvoju nazivlja dali su stoici, osobito Hrisip (III. st. pr. Kr.). ${ }^{8}$ Imenice su dijelili na opće i vlastite (övop $\alpha$ je njihov naziv za vlastito ime, $\pi \rho \circ \sigma \eta \gamma o \rho i ́ \alpha$ za apelativ). Ta se podjela zadržala, ali ne i nazivi, te je óvou $\alpha$ postao naziv za imenicu ili imensku riječ. Naziv $\pi \tau \tilde{\omega} \sigma \iota \varsigma$ ograničili su na imenice te razlikovali nominativ ( $\dot{\eta}$

5 Grčka gramatičarska tradicija prikazana je prema Robins (1967: 9-40), Ivić (2001: 19-27) i Matthews (2007).

6 »Gotovo sve značajnije ličnosti antičke filozofije upuštale su se, bar usputno, u teoretisanje o jeziku« (Ivić 2001: 20).

7 Kotzia govori u prvome redu o razvoju grčkoga filozofskoga vokabulara te prikazuje stoike u tome kontekstu (Kotzia 2007). Blank i Atherton navode Fredeovo istraživanje, prema kojemu su stoici smatrali da »dijelovi iskaza« (tj. vrste riječi) pripadaju grani dijalektike koja se bavila »onime što označuje«, a sintaksa grani koja se bavila »onime što je označeno« (Blank i Atherton 2002: 314). Čini se da ono što Kotzia prevodi kao »logika« Blank i Atherton prevode kao »dijalektički dio logike« (ibid. 314). Mi ćemo koristiti izraz »logika«.

8 Stoička gramatička teorija i nazivlje opisani su prema Blank i Atherton (2003). 
$\dot{o} \rho \theta \eta \dot{\eta}$, sc. $\pi \tau \tilde{\omega} \sigma l \varsigma)$ od kosih padeža. ${ }^{9}$ Naziv $\dot{\rho} \tilde{\eta} \mu \alpha$ 'glagol' definirali su kao ono što označava predikat i nema padeže. Unutar glagolskoga sustava proučavali su kategorije vremena, stanja i tranzitivnosti: razlikovali su prijelazne glagole (o $\rho \theta \dot{\alpha})$, neprijelazne

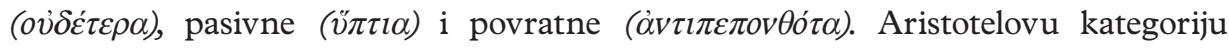
$\sigma v ́ v \delta \varepsilon \sigma \mu o \varsigma$ razdvojili su na sklonjive i nesklonjive riječi te je naziv $\sigma v ́ v \delta \varepsilon \sigma \mu o \varsigma$ označavao veznik, a $\alpha$ $\rho \theta \rho o v$ član. Član je za stoike bio $\dot{\omega} \rho \imath \sigma \mu \varepsilon ́ v o v$ 'određeni' (što zapravo

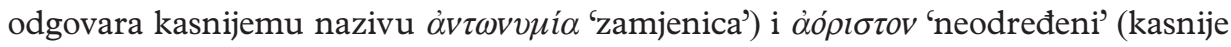

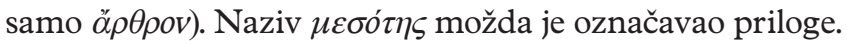

Stoičko su učenje razradili aleksandrijski filolozi. Zahvaljujući njima gramatika se odvojila od filozofije i postala samostalna znanstvena disciplina koja uključuje izradu rječnika i sholija, glosiranje i retoriku. Od aleksandrijskih filologa ističemo Aristarha sa Samotrake (oko 216. - 144. pr. Kr.) i njegova učenika Dionizija Tračanina (oko 170. pr. Kr. - oko 90. pr. Kr.). Potonji je najvjerojatnije napisao Gramatičko umi-

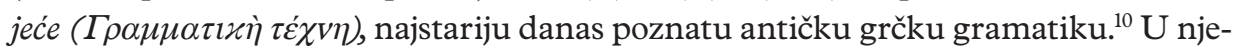
mu se bavio prvenstveno fonologijom i morfologijom, vrlo malo sintaksom, a u dodatku se osvrnuo na dijakritičke znakove i metriku. ${ }^{11}$ Može se podijeliti na tri razine proučavanja: slova/glasovi, slogovi i riječi (Bécares Botas u Dionisio Tracio 2002: 19-20). Gramatičko umijeće smatra se jednom od najutjecajnijih europskih gramatika i djelom koje je »udarilo temelje klasičnoj gramatičkoj terminologiji.$^{12}$ Međutim, nije sasvim sigurno da joj je autor bio Dionizije te je neki smještaju u III. st. (Matthews 2007: 1193) ili IV. st. (Di Benedetto prema Škiljanu u Dionizije Tračanin 1995: 15). Škiljan smatra da je svakako riječ o koherentnome tekstu i sklon je pripisati ga Dioniziju (Dionizije Tračanin 1995: 17, detaljna argumentacija ibid. 15-18). Bécares Botas ističe da nije toliko važno autorstvo koliko činjenica da tekst Gramatičkoga umijeća vjerno prikazuje »duh... i konceptualni i terminološki sustav aleksandrijske filologije« (Dionisio Tracio 2002: 25).

Gramatička rasprava koja nadopunjava Gramatičko umijeće bila je $O$ skladnji

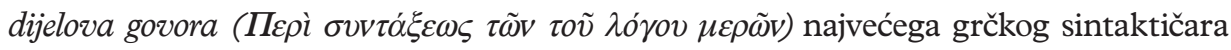
Apolonija Diskola (prva polovica II. st.). On je preuzeo stoički koncept sintakse (Blank i Atherton 2003: 320). Apolonijev sin Herodijan bavio se prozodijom, ali nažalost od njegova opsežnoga opusa sačuvano je samo djelo O osobenim riječima i kasniji ekscerpti. ${ }^{13}$

9 Drugi gramatičari koriste se i nazivom $\varepsilon \dot{v} \theta \varepsilon \tilde{\imath} \alpha$ (Blank, Atherton 2003: 325-326). Dionizije Tračanin i Apolonije Diskol koriste se obama nazivima za nominativ.

10 Dionizije Tračanin (1995), Dionisio Tracio (2002).

11 O bavljenju sintaksom v. poglavlje $O$ vezniku (Dionizije Tračanin 1995: 188-201) i Škiljanov komentar (ibid. 367-373).

$12 H E, »$ Dionizije Tračanin«.

13 Pripisivao mu se i rječnik Fileter, o kojemu će biti riječi u kasnijim poglavljima ovoga rada. Fragmente iz Herodijana objavio je Dain zajedno s Fileterom (Dain 1954). 
I Gramatičko umijeće i Apolonije Diskol znatno su utjecali na rimske gramatičare. Rimljani su stvarali latinsko nazivlje po uzoru na grčko, često prevođenjem i kalkiranjem:

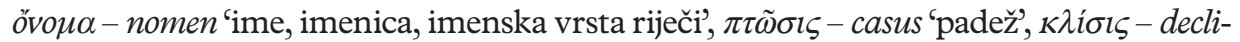
natio 'deklinacija'.

U nastavku donosimo sažet popis gramatičkih naziva kod Dionizija Tračanina i Apolonija Diskola. Popisi su sastavljeni prema kazalima koja donose Škiljan (Dionizije Tračanin 1995: 387-394), odnosno Lallot (Apollonius Dyscole 1997: 423-439), odakle su preuzeti i prijevodi naziva. Nazivi su Apolonija Diskola preuzeti i s Logeiona jer Lallot sam kaže da mu nije cilj ponuditi prijevode te prvenstveno navodi kontekst u kojemu se naziv pojavljuje (Apollonius Dyscole 1997: 423). Jedan je od problema u prikazivanju antičkoga nazivlja što svaki priređivač sam odlučuje o tome što je terminus technicus, a što ne. Primjerice, Škiljan u svoje kazalo ne uključuje naziv

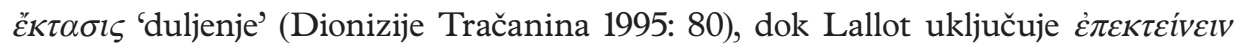
'produljiti' (Apollonius Dyscole 1997: 429). Zbog prostornoga ograničenja odabrani su nazivi za koje smatramo da su poznati hrvatskoj publici (izostavljeni su, primjeri-

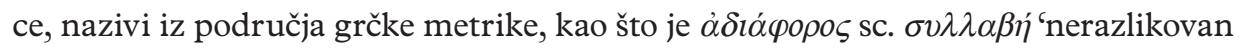

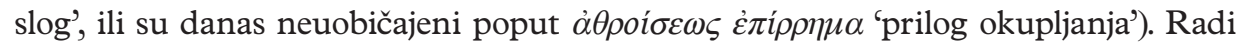
lakšega snalaženja i preglednosti podijeljeni su prema razinama jezičnoga opisa. Navodimo ih u onome obliku u kojemu ih navode priređivači.

Odabrano nazivlje iz Gramatičkoga umijeća Dionizija Tračanina:

- fonologija: $\beta \rho \alpha \chi \varepsilon \tilde{i} \alpha$ sc. $\sigma v \lambda \lambda \alpha \beta \eta^{\prime}$ kratak slog', $\beta \rho \alpha \chi \nu े$ sc. $\varphi \omega v \tilde{\eta} \varepsilon v$ 'kra-

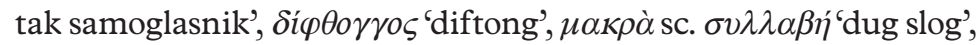

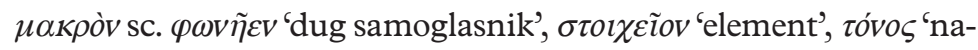
glasak', $\varphi \omega v \tilde{\eta} \varepsilon v$ sc. $\sigma \tau o \imath \chi \varepsilon i ̃ o v ~ ' s a m o g l a s n i k$ ',

- morfologija: $\alpha i \tau \imath \alpha \tau \imath \kappa \eta$ 'akuzativ', $\alpha v \tau \omega v v \mu i \alpha$ 'zamjenica', $\alpha o ́ o l \sigma \tau o \varsigma$

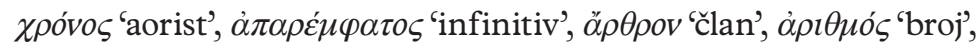

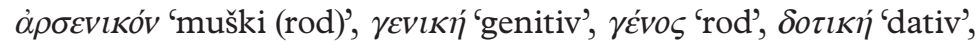
$\dot{\varepsilon} v \varepsilon \varepsilon \gamma \varepsilon l \alpha$ 'aktiv', $\dot{\varepsilon} \pi \pi i \rho \eta \mu \alpha$ 'prilog', $\varepsilon \dot{v} \theta \varepsilon \tilde{i} \alpha$ 'uspravni padež (tj. nomi-

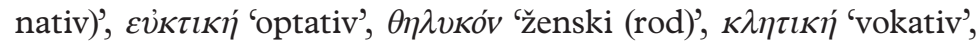

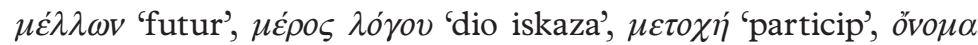

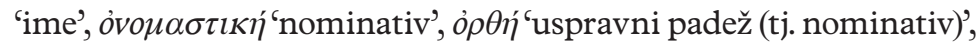
ó

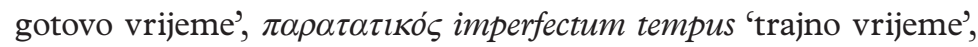

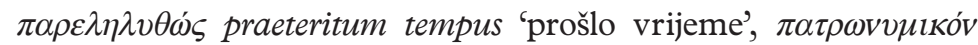

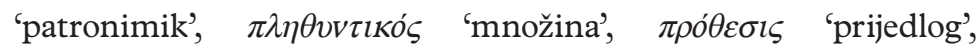

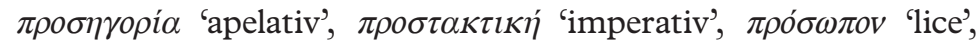

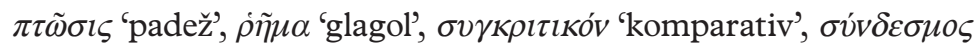

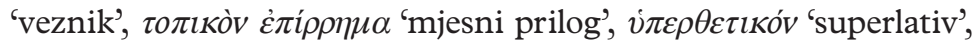




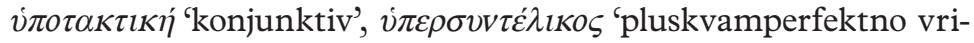
jeme', $\chi \rho o ́ v o \varsigma ~ ' v r i j e m e '$,

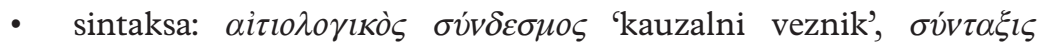
'sintagma',

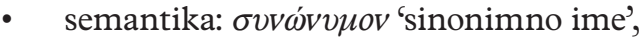

- ostalo: Stóvota 'misao'.

Odabrano nazivlje iz O skladnji dijelova govora Apolonija Diskola:

- fonologija: $\delta l \pi \lambda \alpha \sigma l \alpha ́ \zeta \varepsilon l v$ 'reduplicirati', $\dot{\varepsilon} \pi \varepsilon \kappa \varepsilon \varepsilon i ́ v \varepsilon l v$ 'produljiti',

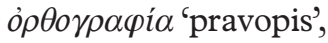

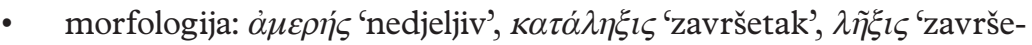

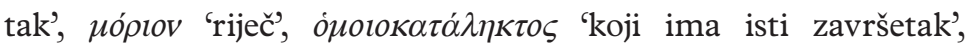
$\pi \alpha \rho \alpha ́ \gamma \varepsilon \varepsilon v$ 'izvoditi', $\pi \alpha \rho \alpha \sigma \chi \eta \mu \alpha \tau \iota \sigma \mu o ́ \varsigma$ 'derivacija, izvođenje', $\pi \lambda \dot{\alpha} \gamma i o \varsigma$ 'kosi padež', $\tau \dot{\pi} \pi \circ \varsigma$ 'oblik, način tvorbe',

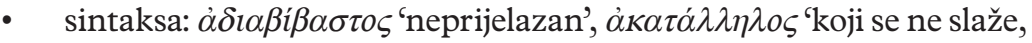

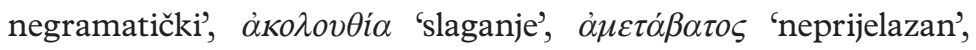

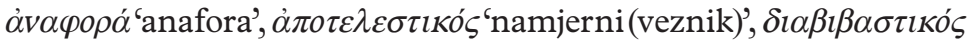
'prijelazan', $\varepsilon \lambda \lambda \lambda \varepsilon \imath \psi \iota \varsigma$ 'elipsa', $\dot{\varepsilon} \pi \imath \tau \dot{\sigma} \sigma \sigma \varepsilon l v$ 'staviti iza, postponirati', $\mu \varepsilon \tau \alpha \beta \imath \beta \alpha ́ \zeta \varepsilon l v$ 'prelaziti', $\sigma v v \tau \dot{\sigma} \sigma \sigma \varepsilon l v$ 'konstruirati, slagati', $\sigma v ́ v \tau \alpha \xi l \varsigma$

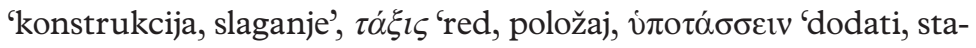
viti iza, subordinirati', ${ }^{14}$

- semantika: $\delta \eta \lambda o \tilde{v} v$ 'označavati', $\delta v v \eta \tau \imath \kappa o ́ \varsigma$ 'potencijalni', $\pi \varepsilon \rho \imath \sigma \sigma o ́ \varsigma$

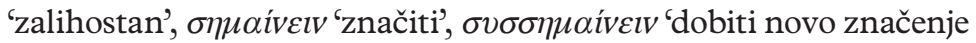
iz konteksta',

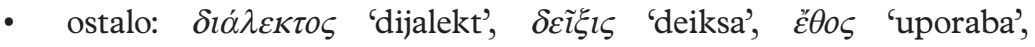

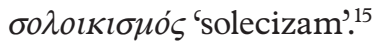

\subsection{Grčka leksikografija}

Već spomenuti aleksandrijski filolozi mogu se smatrati i začetnicima grčke leksikografije. ${ }^{16}$ Bavili su se priređivanjem starih tekstova, primjerice Homera i Pindara, te

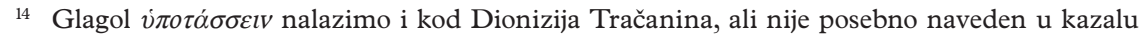
(Dionizije Tračanin 1995: 158).

15 Naziv $\delta \varepsilon \tilde{\imath} \xi \iota \varsigma$ nalazimo i kod Dionizija Tračanina, ali nije posebno naveden u kazalu (Dionizije Tračanin 1995: 166).

16 Povijest grčke leksikografije prema relevantnim natuknicama u Leksikonu antičkih autora (Škiljan 1996) te pregledima koje donose Dickey (2007: 87-102) i Vessella (2018: 14-26), a o aticističkoj 
pripremanjem pomoćnih materijala koji će olakšati njihovo razumijevanje: komentara, sholija i popisa riječi. Objavljivali su i razne glosare: popise rijetkih riječi i izraza, ne nužno povezane s jednim autorom ili djelom. Učeni pjesnik Kalimah autor je Popisa Demokritovih glosa i spisa i Lokalnoga nazivlja. Zenodot iz Efeza (IV./III. st. pr. Kr.) autor je djela Homerovi izrazi i Dijalekatske riječi, a Aristofan iz Bizantija (III./II. st. pr. Kr.) O nazivima za životna doba i O izrazima za koje je sumnjivo da li su ih upotrijebili drevni pisci. Aristofanov je suvremenik bio Filemon, autor jednoga popisa atičkih riječi od kojega su sačuvani samo citati kod drugih pisaca. ${ }^{17}$ U II. st. Harpokration je sastavio Leksikon desetorice govornika, priručnik za snalaženje u atenskome pravu koji je danas važan izvor jezičnih, književnih i prozopografskih podataka. Njegov suvremenik Julije Polideuk sastavio je Imenik, tematski organiziran leksikon koji donosi obilje informacija o klasičnoj književnosti, osobito važan kao izvor za povijest kazališta.

U II. st. djeluju atički leksikografi Elije Dionizije i Pauzanija, koji su u svojim rječnicima naveli atičke riječi i izraze poredane po alfabetu. Njima su bliski aticistički leksikografi iz II. i III. st. Taj korpus čine Frinih, djelo Antiaticist anonimnoga autora, Filemon, Merid te leksikon Fileter, koji se pripisivao Herodijanu, sinu Apolonija Diskola. Oni također navode atičke oblike, ali pritom zauzimaju puristički i preskriptivistički stav te se često pozivaju na uzorne govornike grčkoga (što su najčešće atenski autori zlatnoga doba) kad preporučaju određenu riječ, odnosno prozivaju neprihvatljive govornike kad kritiziraju neku jezičnu pojavu. Nisu svi aticistički leksikografi bili jednako kritični. Najstroži aticist bio je Frinih (Strobel 2009: 100), dok je autor Antiaticista daleko blaži i donosi širi popis prihvatljivih autora - zbog tog je odstupanja od uobičajenoga aticističkoga kanona i naslovljen Antiaticist. Odstupanja nalazimo i kod Merida koji je među uzorne pisce uključio i Homera i Herodota iako njihovo književno narječje nije atičko, nego jonsko. Budući da su aticistički leksikografi vremenski vrlo bliski, filolozi pokušavaju utvrditi u kakvome su odnosu njihova djela. Proučavanje antičke grčke leksikografije otežava i činjenica da su, osim Friniha, Merida, Filetera i Antiaticista, leksikografska djela ili vrlo slabo sačuvana ili nisu dostupna u pouzdanim modernim izdanjima. ${ }^{18} \mathrm{U}$ navedenim četirima djelima može se primijetiti da Antiaticist i Merid predstavljaju svoje jezične savjete u sažetijim natuknicama od Friniha: u Antiaticistu nema otrovnih napada na »neuke« govornike, nego se samo navode izvori, a Merid se rijetko udaljava od osnovnoga oblika

leksikografiji također i prema Strobel $(2005,2009)$ i Lee (2013). Ovdje uključujemo i glosatore, iako ih Ivić razlikuje od leksikografa: leksikografi skupljaju i njeguju rječničko blago, a glosatori se bave teškim, dijalekatskim i pjesničkim oblicima (Ivić 2001: 24).

17 Treba ga razlikovati od aticista Filemona koji je živio oko 200. god. i koji se spominje u sljedećem odlomku.

18 Dostupna moderna izdanja: Phrynichos (1974), Moeris (1998), Dain (1954) i Valente (2015). 
natuknice u kojemu suprotstavlja dvije riječi 'A je atički, B je opće/grčki'. ${ }^{19}$ Fileter i Frinih donose i neke duže natuknice te upotrebljavaju različite jezikoslovne nazive (više u 5. i 6. poglavlju).

Od kasnijih leksikografa spomenut ćemo samo neke. Na temelju građe iz II. st. nastao je rječnik sinonima koji se pripisivao Hereniju Filonu i Amoniju. U V. ili VI. st. Hesihije iz Aleksandrije kompilirao je zbirku pjesničkih i dijalekatskih riječi, izraza i poslovica. U X. st. nastao je rječnik Suda, koji je blizak današnjim rječnicima enciklopedijskoga tipa i vrlo je vrijedan izvor podataka o antičkim piscima (između ostaloga i Frinihu). Bizantska tradicija uključuje i nekoliko rječnika poznatih pod zajedničkim nazivom Etymologica, međutim, nije riječ o etimološkim rječnicima u današnjemu značenju riječi, nego o rječnicima koji u natuknicama donose razna objašnjenja, od kojih su neka etimološka.

\section{Frinihov Izbor}

\subsection{Frinih}

O Frinihu se zna vrlo malo. Živio je u II. st. i bio je rodom iz Bitinije. Poznata su nam

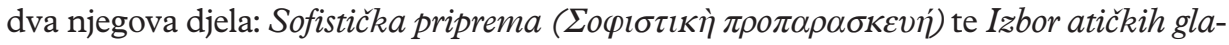

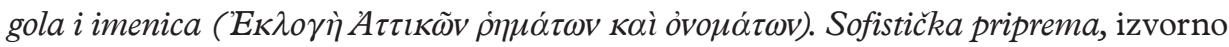
u 37 knjiga, donosi savjete kako se lijepo izražavati i pismeno i usmeno. Sačuvani su skraćena inačica, fragmenti i Fotijev sažetak (Swain 1996: 54). Djelo čine natuknice poredane po prvome slovu, mnoge preuzete iz djela koja su nam danas izgubljena (Dickey 2007: 97). Danas je dostupno u De Borriesovu izdanju (Phrynichus 1911).

\subsection{Izbor}

Frinihov Izbor atičkih glagola $i$ imenica sačuvan je u više-manje izvornoj inačici, u dvjema knjigama. Vjerojatno je objavljen početkom 160-ih (Swain 1996: 53). ${ }^{20}$ Djelo se često spominje u pregledima razvoja grčkoga jezika nakon klasičnoga doba zbog izrazito konzervativne reakcije na jezične promjene, što ga čini korisnim izvorom za njihovo poznavanje (v. npr. Browning 1983: 47-48, Horrocks 2010: 138-139, Andriōtēs 2005: 59-62). U Izboru Frinih navodi niz oblika, navedenih u zasebnim natuknicama, koje bi govornici grčkoga trebali izbjegavati ako ne žele zvučati neuko i neobra-

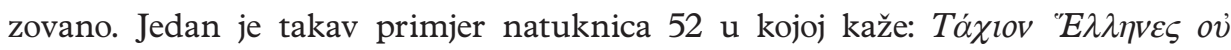

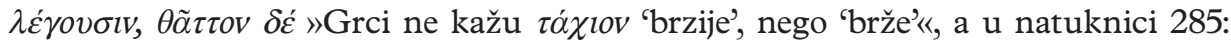

\footnotetext{
19 Više o Meridu i njegovu često nejasnome stilu donosi Swain (1996: 51-52).

20 Ali Lee ga smješta u 178. (Lee 2013: 288).
} 


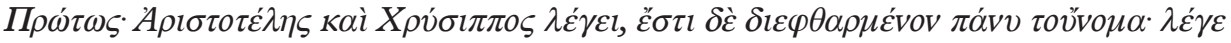

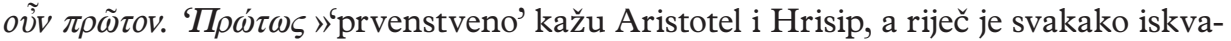
rena - reci dakle $\pi \rho \tilde{\omega} \tau o v$ 'ponajprije'«. ${ }^{21}$ Frinih često navodi i razloge za uporabu određene riječi i protiv nje. Riječi i uporabu koje kritizira katkad dodatno opisuje kao solecizme $(118,128,140)$, barbarizme $(298,300,306)$, dijalekatske (101, 117, 272, 286), pučke (176) ili pjesničke riječi $(106,247,251,294)$, a uz riječi koje preporuča navodi da su posvjedočene kod uzornih pisaca poput Platona, Demostena i Aristofana. Uzorni pisci mahom pripadaju zlatnomu dobu Atene, ali povremeno Frinih odstupa od toga te iznimno smatra valjanima čak i neke homerske (324) ili pjesničke eolske oblike (280). ${ }^{22} \mathrm{~S}$ druge strane, Ksenofont, pisac klasičnoga doba koji se smatrao uzorom jasnoga stila, nalazi se na meti Frinihovih kritika jer je »zgriješio protiv materinskoga jezika« (62). Vrijedi spomenuti da se Frinih, koliko god zagovarao atičku uporabu kao jedinu prihvatljivu, katkad ni sam ne pridržava pravila koja tako gorljivo zastupa: primjerice, u natuknicama 51 i 81 ne koristi se dvojinom iako uporabu toga broja promiče u natuknicama 180 i 181, a često se usporedno koristi atičkim i neatičkim

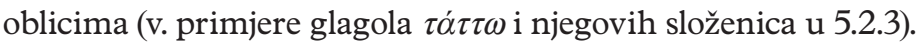

Redoslijed Frinihovih natuknica nije sasvim jasan: Fischer primjećuje da su neke skupine natuknica poredane alfabetski i smatra vjerojatnim da je riječ o natuknicama preuzetim iz drugih leksikografskih izvora (Phrynichos 1974: 38). Fischer smatra da se Frinih oslanjao na djela drugih grčkih leksikografa, npr. Elija Dionizija i Polideuka, te da se koristio istim izvorima kao Merid i Fileter (Phrynichos 1974: 39-44); Vessella pak smatra da se Merid oslanja na Frinihov Izbor (Vessella 2018: 20). Različita mišljenja postoje i o odnosu između Friniha i Antiaticista. Dickey navodi da se Antiaticist smatrao djelom Frinihova suvremenika i reakcijom na prvu knjigu Frinihova Izbora, na koju je pak Frinih reagirao drugom knjigom Izbora. S druge strane, postoje i mišljenja da napadi na Antiaticista nisu ograničeni na drugu knjigu Izbora te da se Frinih koristio Antiaticistom kao građom za Izbor, i obrnuto (Dickey 2007: 97). Iako se i Frinih i Antiaticist smještaju u II. st., teško je doći do konkretnoga zaključka dok se ne utvrdi točna datacija djela.

${ }^{21}$ Frinih se u ovome radu citira prema izdanju Fischer (Phrynichos 1974). U primjerima iz Frinihova Izbora grčke se riječi navode u izvorniku, uz ponuđenu hrvatsku istovrijednicu.

22 Iako su obje pisale na eolskome književnom narječju, pjesnikinja Sapfo neprihvatljiva je u natuknici 272, a Korina prihvatljiva u 280. 


\section{Jezikoslovno nazivlje u Frinihovu Izboru}

\subsection{Znanstveno nazivlje u opreci s neznanstvenim opisom jezične prakse}

Riječi kojima se Frinih služi u jezičnome opisu mogu se podijeliti u dvije skupine. Prvu čine gramatički nazivi koje, kako je objašnjeno ranije, možemo smatrati znanstvenima i o kojima će biti riječi u ostatku članka, a drugi dio čine izrazi kojima Frinih opisuje jezičnu praksu. Njih ne možemo smatrati znanstvenima jer prije svega sadržavaju Frinihove vrijednosne sudove o tome koja je riječ prihvatljiva, a koja nije. Mnoge riječi čiju uporabu Frinih pokušava zabraniti danas su dio standardnoga vokabulara u novogrčkome. Povrh toga, da bi potkrijepio svoje teze o neprihvatljivosti pojedinih riječi, Frinih nerijetko opisuje govornike kao »neuke«, a njihovu jezičnu praksu kao »barbarsku« (298 i dr.) i »gnjusnu« (41). Ono što bi se danas stručno okarakteriziralo kao dijalektalno, supstandardno ili žargonsko, za Friniha je jednostavno pogrešno i loše. Iz današnje perspektive osobito bizarnima djeluju njegovi žučljivi napadi na pisce koji su živjeli nekoliko stoljeća ranije, npr. na već spomenutoga prozaika Ksenofonta (V./IV. st. pr. Kr.), te komediografa Menandra (IV./III. st. pr. $\mathrm{Kr}$.), kojega u natuknici 402 proziva da »nagrđuje materinski jezik« - što je kao da npr. proučavatelji hrvatskoga standardnog jezika oštro osude jezičnu praksu Ivana Gundulića zbog njegovih povremenih odstupanja od štokavske jekavštine. ${ }^{23}$

\subsection{Jezikoslovno nazivlje u Izboru po razinama jezičnoga opisa}

\subsubsection{Neke napomene}

U radu znanstvenim nazivljem smatramo nazive kojima Frinih opisuje jezik bez izricanja kvalitativnih sudova. ${ }^{24}$ Jezikoslovno je nazivlje ono koje se može povezati s četirima razinama jezičnoga opisa: fonologijom, morfologijom, sintaksom i semantikom, te se može naći u popisima tehničkih naziva u Lallotovu izdanju Apolonija Diskola (Apollonius Dyscole 1997), Škiljanovu izdanju Dionizija Tračanina (Dionizije Tračanin 1995) i Vessellinoj studiji aticističkoga izgovora (Vessella 2018). Vessella se u sklopu proučavanja aticističkih rječnika bavio Frinihovim fonološkim nazivljem, no njegova je studija u prvome redu posvećena istraživanju grčkoga glasovnoga sustava u II. st.

23 Blanchard smatra da su upravo Frinihove kritike upućene Menandru razlog zašto je taj pisac dugo bio zanemarivan (Blanchard 1997). O Gundulićevu jeziku navodimo: »Pjesnički jezik Gundulićeva književnog opusa, štokavska jekavština s mnogobrojnim ikavizmima i nekoliko ekavizama, smatra se najbogatijim pjesničkim jezikom starije hrvatske književnosti« (prema $H E$, Gundulić, Ivan«).

24 Nazivi za dijalekte i riječi izvedene od njih, npr. $\delta \omega \rho i \zeta \omega$ 'imitirati dorski dijalekt, govoriti dorski' (401), nisu uključeni u naš popis jer nisu povezani isključivo s gramatikom. 
Vesella se osvrnuo na problem višeznačnosti nekih naziva i njihove uporabe (Vessella 2018: 28-30). On navodi primjere Frinihove uporabe glagola $\lambda \varepsilon \dot{\gamma} \omega$ i $\pi \rho \circ \varphi \varepsilon ́ \rho \omega$ u značenju 'reći', 'govoriti', iako u užemu smislu mogu značiti 'izgovarati' (Vessella

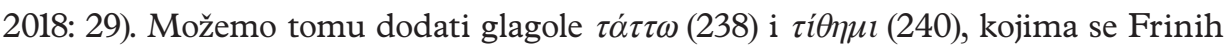

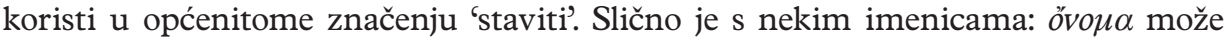
značiti 'riječ', a u užemu značenju 'imenica'; $\varphi \omega v \eta$ (24) znači 'glas' i 'riječ'; $\sigma \chi \eta ́ \mu \alpha$ može značiti 'ustroj rečenice' ili 'oblik riječi', no u natuknici 357, u kojoj se dvaput pojavljuje, ima najopćenitije značenje - 'oblik'. ${ }^{25}$ Takve riječi nisu uvrštene u naš popis kad su upotrijebljene u najopćenitijemu značenju te nisu uzete u obzir natuknice

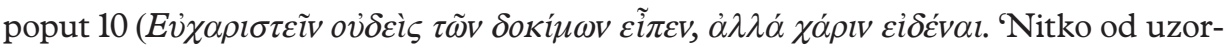

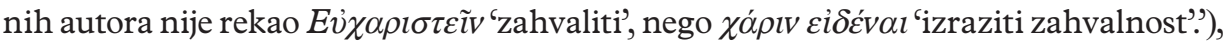
u kojoj glagolski oblik $\varepsilon \tilde{i} \pi \varepsilon v$ nema značenje 'izgovarati', nego jednostavno 'reći' - u natuknici nije riječ o fonološkoj, nego o leksičkoj promjeni. Nisu uzete u obzir ni natuknice u kojima je moguće i jedno i drugo značenje, npr. övo $\mu \alpha$ u natuknicama 222,226 i 231.

Ovdje donosimo pregled nazivlja podijeljenoga u skupine po pojedinim razinama jezičnoga opisa i navedenoga redoslijedom pojavljivanja. Nakon broja natuknice slijedi naziv i broj njegovih pojavljivanja unutar natuknice ako je veći on od jedan. Taj pregled ne odgovara podjeli natuknica po sadržaju: u nekim natuknicama nema nikakvoga znanstvenog nazivlja (npr. 1, 4, 5, 8, 10, 12, 14, 16, 18, 19, 20, 21, 25). Isto tako, činjenica da se u nekoj natuknici upotrebljavaju npr. morfološki nazivi ne znači nužno da je natuknica posvećena nekoj morfološkoj osobitosti (npr. 207 u kojoj se

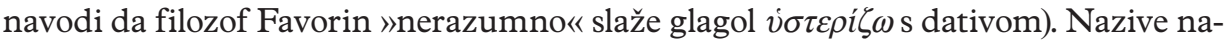
vodimo u rječničkome obliku (imenske vrste riječi u nominativu jednine, glagole u 1. licu jednine indikativa prezenta), osim priloga koji se, kao i kod Vesselle, navode zasebno (Vessella 2018).

\subsubsection{Fonološko nazivlje ${ }^{26}$}

$2 \lambda \dot{\varepsilon} \gamma \omega, 15 \lambda \dot{\varepsilon} \gamma \omega, 17 \lambda \varepsilon^{\prime} \gamma \omega, 22 \lambda \dot{\varepsilon} \gamma \omega \times$ 3, $26 \lambda \dot{\varepsilon} \gamma \omega, 36 \lambda \dot{\varepsilon} \gamma \omega \times 2,39 \lambda \dot{\varepsilon} \gamma \omega, 54 \lambda \dot{\varepsilon} \gamma \omega \times$ 3, 59 $\lambda \dot{\varepsilon} \gamma \omega, \sigma v \lambda \lambda \alpha \beta \dot{\eta}, \tau \varepsilon \tau \rho \alpha \sigma v \lambda \lambda \dot{\alpha} \beta \omega \varsigma, 62 \lambda \dot{\varepsilon} \gamma \omega, 72 \pi \rho \circ \varphi \circ \rho \alpha \dot{x}$ 2, $77 \beta \rho \alpha \chi v \dot{v} \omega, \dot{\varepsilon} \kappa \tau \varepsilon \dot{v} \omega, 81$

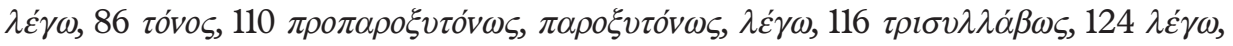
$127 \dot{\varepsilon} \pi \varepsilon \kappa \tau \varepsilon \dot{v} \omega \omega, \lambda \dot{\varepsilon} \gamma \omega, 129 \tau \rho \imath \sigma v \lambda \lambda \alpha \dot{\alpha} \beta \omega \varsigma, \delta \imath \sigma v \lambda \lambda \dot{\alpha} \beta \omega \varsigma, 139 \delta \imath \alpha \imath \rho \dot{\varepsilon} \omega, 140 \delta \imath \sigma v \lambda \lambda \dot{\alpha} \beta \omega \varsigma$,

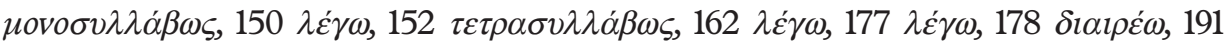

$25 \mathrm{U}$ natuknici 357 također nalazimo niz 'ôvo $\mu \alpha, \beta \lambda \varepsilon \dot{\mu} \mu \alpha, \varphi \omega v \eta ́, \sigma \tau \alpha \dot{\sigma} \iota \varsigma$ ', koji na prvi pogled izgleda kao da sadržava dva gramatička naziva, međutim ovdje Frinih samo oponaša govornika Demostena, također spomenutoga u toj natuknici, koji je u jednome govoru upotrijebio prve tri riječi istim redoslijedom, samo u drugome padežu: $\tau \tilde{\omega} \sigma \chi \eta_{\mu} \alpha \tau \imath$, $\tau \tilde{\omega} \beta \lambda \varepsilon \dot{\varepsilon} \mu \alpha \tau \imath, \tau \tilde{\eta} \varphi \omega v \tilde{\eta}(21.72)$.

26 Prijevodi svih naziva nalaze se u 5.3. 


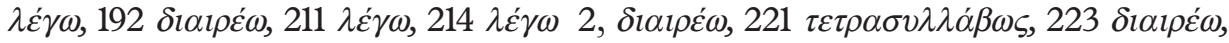

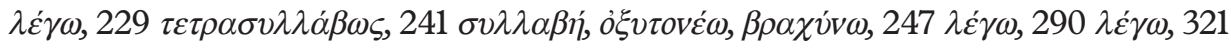

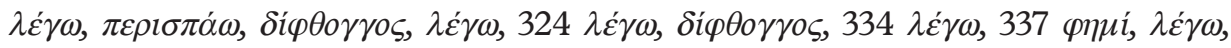


$\tau \rho \iota \sigma v \lambda \lambda \dot{\alpha} \beta \omega \varsigma, \tau \varepsilon \tau \rho \alpha \sigma v \lambda \lambda \dot{\alpha} \beta \omega \varsigma, \pi \rho \circ \varphi \varepsilon ́ \rho \omega, 405 \sigma v \lambda \lambda \alpha \beta \dot{\eta}, 418 \lambda \dot{\varepsilon} \gamma \omega, 419 \lambda \dot{\varepsilon} \gamma \omega, 420 \lambda \dot{\varepsilon} \gamma \omega$,

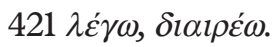

\subsubsection{Morfološko nazivlje}

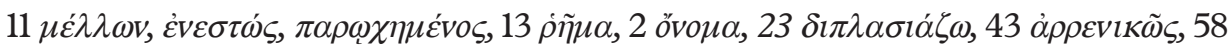

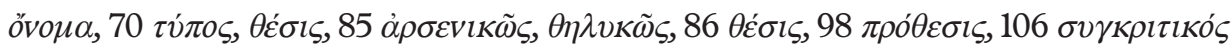

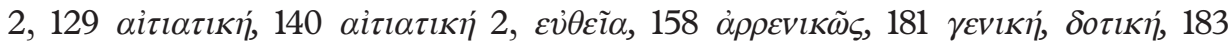

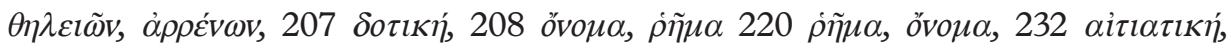

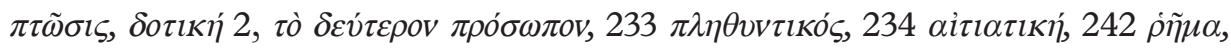

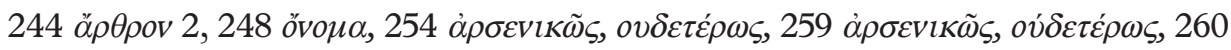

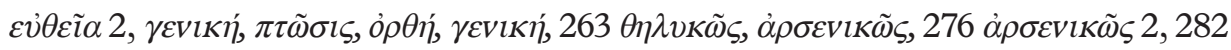



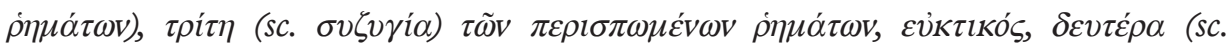

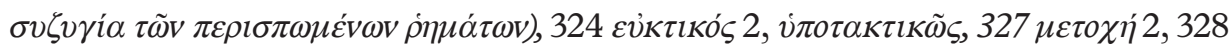

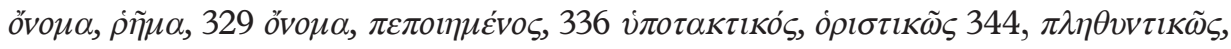

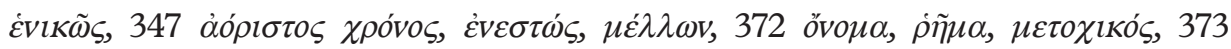

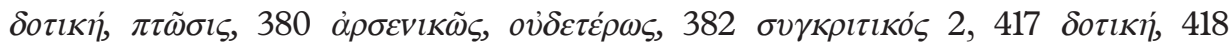

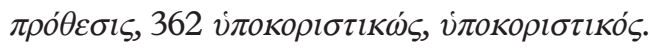

\subsubsection{Sintaktičko nazivlje}

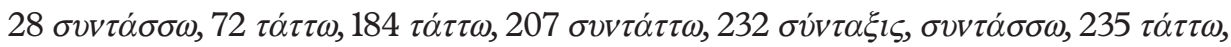

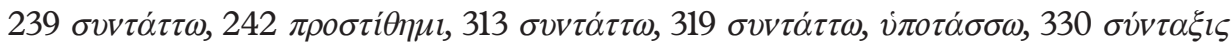

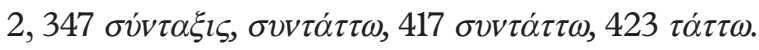

\subsubsection{Semantičko nazivlje}

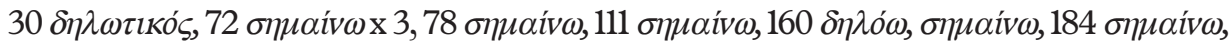

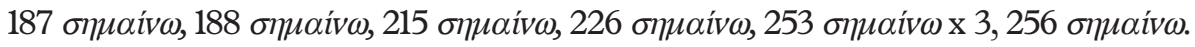

\subsection{Analiza}

Svaka od predstavljenih skupina naziva može se dalje analizirati po značenju i učestalosti naziva te vrstama riječi. Iznesene su i neke pretpostavke o podrijetlu naziva. Na kraju analize slijedi usporedba s Fileterom. 
Fonološki su nazivi u Frinihovu Izboru, od najčešćih prema najrjeđim izrazi-

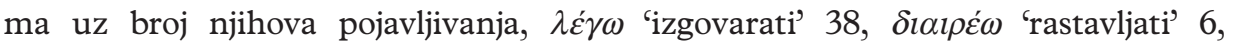

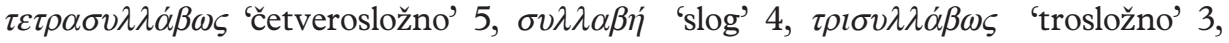

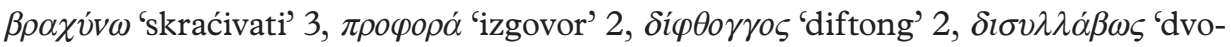

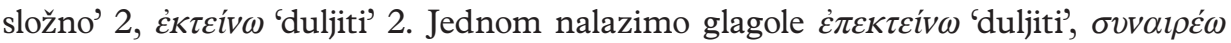

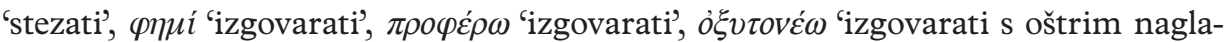
skom na posljednjemu slogu', $\pi \varepsilon \rho \imath \sigma \pi \alpha ́ \omega$ 'izgovarati sa zavinutim naglaskom na po-

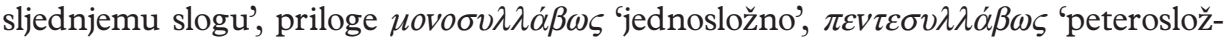
no', $\pi \alpha \rho o \xi v \tau o ́ v \omega \varsigma$ 's oštrim naglaskom na pretposljednjemu slogu', $\pi \rho \circ \pi \rho \rho \xi v \tau o ́ v \omega \varsigma$ 's oštrim naglaskom na trećemu slogu od kraja' te imenicu tóvo 'naglasak'. Fonološko nazivlje uključuje nazive kojima se opisuju izgovor, slogovi, duljina sloga, promjene kod vokala poput duljenja, kraćenja i stezanja te rastavljanje diftonga (dijereza), vrste naglasaka i glasovi. Najčešća su vrsta riječi u fonološkome nazivlju glagoli koji znače ili opisuju izgovaranje: 'izgovoriti', 'stegnuti', 'rastegnuti', 'skratiti', 'produžiti'. Najrjeđe su imenice: 'slog', 'izgovor', 'diftong', 'naglasak'. Nema naziva za vokale i konsonante. Ukupno sedam priloga upotrijebljeno je 14 puta. Oni najčešće opisuju broj slogova, a nešto rjeđe naglasak. Treba istaknuti da uporaba nije dosljedna, npr. od fonološkoga nazivlja Frinih se koristi samo nazivom za diftonge iako vrlo često obrađuje glasovne promjene kod vokala. Često se koristi nazivima za broj slogova. U fonološkome nazivlju najvažnije mu je bilo ono što se odnosi na izgovor i na razinu sloga, a ne na vokalski ili konsonantski sustav. Glasovima i slogovima osobito se bavio Dionizije Tračanin, no primjerice glagol $\dot{\varepsilon} \pi \varepsilon \kappa \tau \varepsilon i v \omega$ 'duljiti' nalazimo kod Apolonija

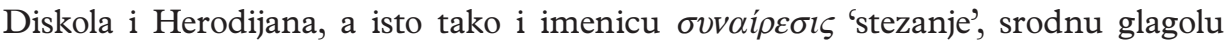

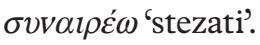

Morfološko nazivlje čine, poredani prema učestalosti sljedeći nazivi: $\dot{\alpha} \rho \rho \varepsilon v l \kappa \tilde{\omega} \varsigma$

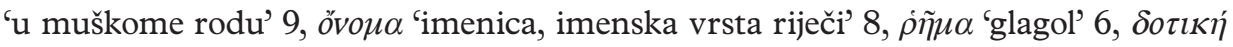

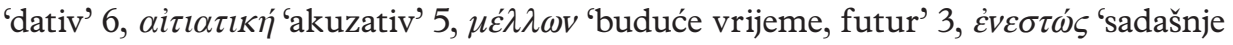

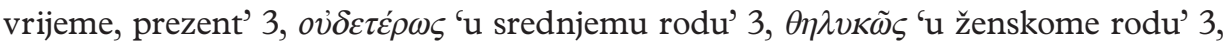

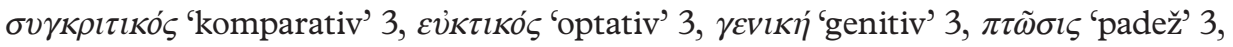

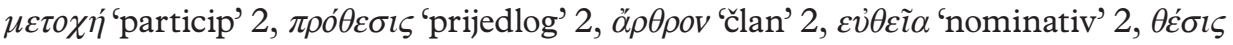
2 'oblik', $o \rho \theta \eta \dot{~ ' n o m i n a t i v ', ~ \mu \varepsilon \tau o \chi ı к o ́ \varsigma ~ ' p a r t i c i p s k i ', ~ \pi \alpha \rho \omega \chi \eta \mu \varepsilon ́ v o \varsigma ~ ' p r o s ̌ l o ~ v r i j e m e ', ~}$

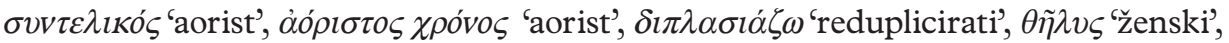



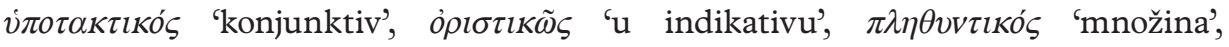
$\pi \lambda \eta \theta v v \tau \imath \kappa \tilde{\omega} \varsigma$ 'u množini', $\dot{\varepsilon} v l \kappa \tilde{\omega} \varsigma$ 'u jednini', $\pi \rho \omega ́ \tau \eta ~ \sigma v \zeta v \gamma i ́ \alpha$ (sc. $\tau \tilde{\omega} v \pi \varepsilon \rho l \sigma \pi \omega \mu \varepsilon \dot{v} \omega v$

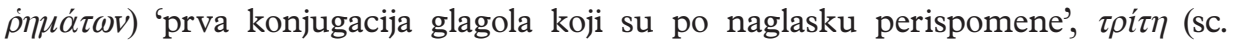

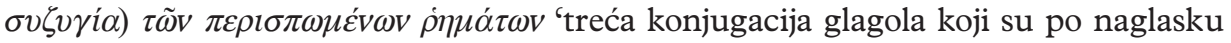

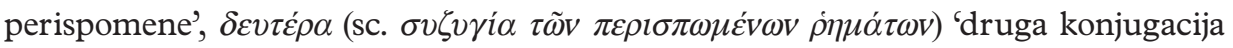

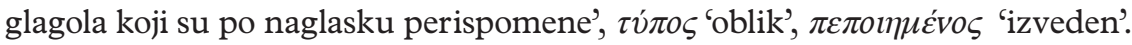


Morfološko nazivlje uključuje nazive za vrste riječi (imenica, glagol, particip, prijedlog), nazivlje povezano s kategorijama roda, broja, padeža, lica, vremena, načina, komparacijom pridjeva, konjugacijama te neke nazive povezane s tvorbom riječi. ${ }^{27}$ Frinih spominje sva tri gramatička roda u grčkome i o njima rado govori priložno, od ukupno 17 naziva samo su dva pridjeva ( $\theta \tilde{\eta} \lambda v \varsigma$, $\ddot{\alpha} \rho \rho \eta v)$. Od brojeva, spominje jednom jedninu i dvaput množinu. Ne upotrebljava naziv za dvojinu iako nekoliko puta u Izboru komentira upotrebu toga broja. Koristi se svim nazivima za padeže koje grčki jezik ima, osim vokativa, čiji status nije bio jasan u antičkoj gramatici. Za nominativ se koristi obama nazivima koja navode Dionizije Tračanin i Apolonije Diskol, $\varepsilon v \dot{\theta} \theta \tilde{\varepsilon} \alpha$ i $\partial \rho \theta \eta \dot{\eta}$. Češće spominje kose padeže nego nominativ: dativ šest puta, akuzativ pet, genitiv tri. Od nazivlja povezanoga s komparacijom koristi se samo nazivom za komparativ ( $\sigma v \gamma \kappa \rho \iota \tau \iota \kappa o ́ s)$. Naziv za lice pojavljuje se samo jednom ( $\tau \grave{o}$ $\delta \varepsilon v ́ \tau \varepsilon \rho \circ v \pi \rho o ́ \sigma \omega \pi \circ v)$. Upotrebljava pet različitih naziva za glagolska vremena: futur,

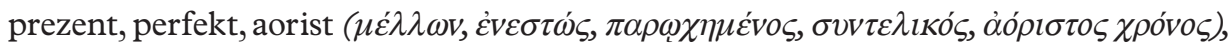
od čega se posljednja dva odnose na aorist. Od nazivlja za načine ne koristi se samo nazivom za imperativ, a koristi se nazivima za optativ, konjunktiv i indikativ

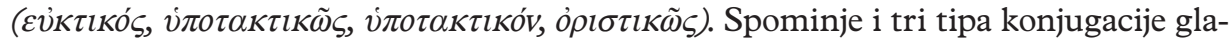
gola koji su po naglasku perispomene, a koje navodi Dionizije Tračanin ( $\pi \rho \omega t \tau$,

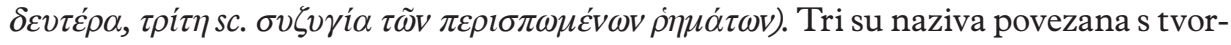

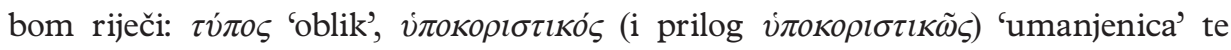

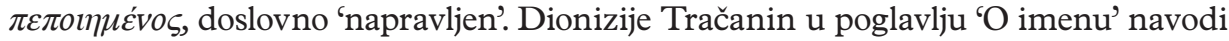

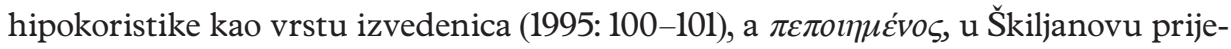
vodu 'skovano', kao jednu od kategorija vrste (ibid. 118-119). Iz primjera koje navodi Dionizije Tračanin očito je da za njega 'skovano' označava onomatopejsku riječ (ibid. 135). Ovdje je Frinih upotrijebio naziv u značenju 'izvedeno' i odstupio od Dionizijeva nazivlja kojeg se pridržavao u imenovanju konjugacija. Valja napomenuti da nije

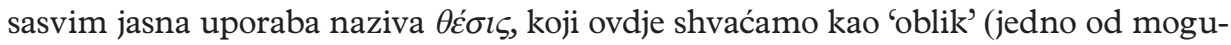
ćih tumačenja prema Lallotu, Apollonius Dyscole 1997: 430).

Za razliku od fonološkoga opisa, Frinih u morfološkome opisu vrlo rijetko upotrebljava glagole. Iznimka je $\delta \imath \pi \lambda \alpha \sigma i \alpha ́ \zeta \omega$ koji znači 'udvostručiti', u gramatici 'reduplicirati'. Reduplikacija je način na koji se u grčkome tvori perfektna osnova. Frinih se koristi tim glagolom kad preporuča pravilan oblik perfektne osnove dvaju glagola te je zbog toga ovdje taj naziv smješten pod morfološko nazivlje. Taj se glagol inače pojavljuje kod Apolonija Diskola. Ni ovdje Frinih nije sustavan te primjerice nikad ne upotrebljava nikakav naziv za prilog iako ne samo da među obrađenim riječima ima nekoliko priloga nego i prilozi čine dio njegova znanstvenoga nazivlja. Isto, kao što je rečeno u prethodnome odlomku, vrijedi i za dvojinu. Za nominativ i aorist upotrebljava dva naziva, što nije neobično jer su oba bila u opticaju u antičko doba.

\footnotetext{
27 Participi su, prema Dioniziju Tračaninu, zasebna vrsta riječi.
} 
Iako poznaje glagolsko nazivlje, mnogo se češće koristi nazivima kojima se opisuju imenske vrste riječi, osobito one povezane s kategorijama roda i padeža. Bavljenje padežima možemo povezati s nestankom dativa u helenističkoj koine, a interes za rod jedno je od najranijih pitanja grčkoga jezikoslovlja (v. 3.1). Interes za glagolsko nazivlje povezujemo s promjenama u glagolskome sustavu, npr. stapanjem perfekta i aorista te postupnim nestankom optativa. Valja napomenuti da se i Apolonije Diskol koristi brojnim fonološkim i morfološkim nazivima, no ne donosi npr. podjelu konju-

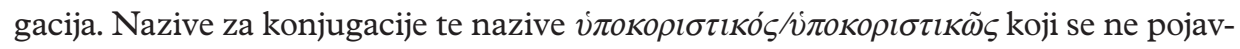
ljuju kod Apolonija Diskola smatramo potvrdom da je Frinih poznavao Gramatičko umijeće. S druge strane, Apolonije Diskol i ovdje je ostavio traga, sudeći prema nazivima $\delta \imath \pi \lambda \alpha \sigma i \alpha ́ \zeta \omega, \theta \varepsilon \dot{\sigma} \sigma \varsigma, \pi \alpha \rho \omega \chi \eta \mu \varepsilon \dot{v} o \varsigma$ i $\tau \dot{\tau} \pi o \varsigma$.

U području sintakse Frinihovo nazivlje čine glagol $\tau \alpha ́ \tau \tau \omega$ 'staviti, složiti' 4,

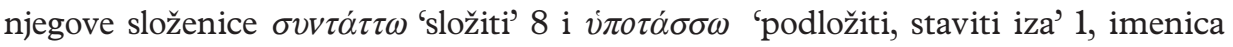

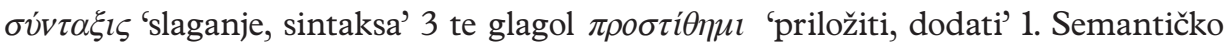
nazivlje uključuje glagole $\sigma \eta \mu \alpha i ́ v \omega$ 'značiti' 15 i $\delta \eta \lambda o ́ \omega$ 'označavati' 1 te od njega izve-

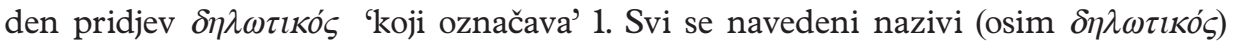
mogu naći kod Apolonija Diskola, uključujući $\pi \rho o \sigma \tau i \theta \eta \mu l$, koji Lallot ne smatra

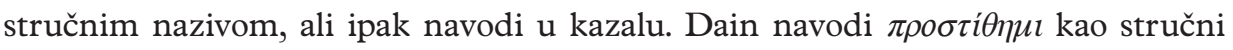

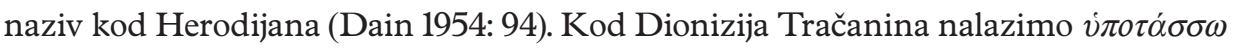

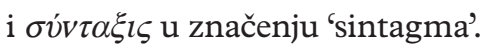

U Frinihovu nazivlju nalazimo podudarnosti s nazivljem kojim su se koristili Dionizije Tračanin, Apolonije Diskol i Herodijan. Smatramo da je Frinih bio upoznat s gramatičkom tradicijom i navedenim djelima iako nije uvijek moguće odrediti od koga je preuzeo koji naziv. Ako je ispravna datacija Izbora u rane 160-e (a moguća je i kasnija), a Frinih je svakako živio u II. st., dakle ili istodobno s Apolonijem Diskolom, kojega se smješta u prvu polovicu II. st., ili nešto nakon njega, te ako se koristio nekim fonološkim i morfološkim nazivima koji se pojavljuju kod Apolonija Diskola, postavlja se pitanje zašto se u Izboru ograničava tek na najosnovnije sintaktičko nazivlje i ne koristi se, primjerice, nikakvim nazivima za prijelazne i neprijelazne glagole. Dakako, činjenica da se ne koristi nekim nazivima ne znači da mu oni nisu bili poznati, kao što se ne koristi svim nazivima za glagolska vremena ili konjugacije koji se pojavljuju u Gramatičkome umijeću. Veći broj naziva s područja fonologije i morfologije nego sintakse i semantike tumačimo Frinihovom željom da ispravi pogreške za koje je isticao da ih čine neobrazovani govornici, za što mu nisu bili potrebni nazivi 'anafora', 'deiksa' ili 'elipsa'. Pogreške koje Frinih i drugi aticistički leksikografi komentiraju pripadaju govornome jeziku (Lee 2013: 285). Na temelju govornoga jezika teže ćemo doći do zaključka o višestruko složenim rečenicama, a lakše o izgovoru. Browning, primjerice, opširno govori o fonološkim i morfološkim promjenama u koine (Browning 1983: 24-28, 28-35), a sažetije o sintaksi (ibid. 36- 
38). Promjene u izgovoru u koine utjecale su i na morfološke promjene jer su se različiti oblici zbog fonoloških promjena počeli isto izgovarati (Browning 1983: 29). Općenito se veći broj Frinihovih natuknica bavi fonologijom i morfologijom nego sintaksom i semantikom (valja istaknuti da se najveći broj natuknica bavi leksikom, ali ne iz semantičke perspektive, nego npr. dijalektološke: navode se atičke riječi kojima bi se trebalo koristiti i jonske ili eolske istoznačnice ili bliskoznačnice kojima se ne smije koristiti). Osim toga, fonološko i morfološko nazivlje imalo je dužu tradiciju (već od Platona, v. 3.1), osobito ako prihvatimo Dionizijevo autorstvo Gramatičkoga umijeća. Smatramo mogućim i da je na Friniha utjecalo stoičko mišljenje da sintaksa i semantika pripadaju drugoj grani logike od vrsta riječi.

\section{Usporedba s Fileterom}

Dain je u svojemu izdanju Filetera, uz koje se nalaze i neki Herodijanovi fragmenti, priredio i kazalo gramatičkih pojmova (Index rerum grammaticarum, Dain 1954: 91-

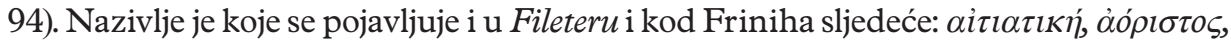

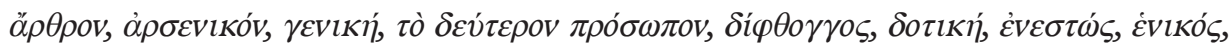

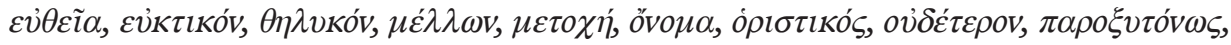

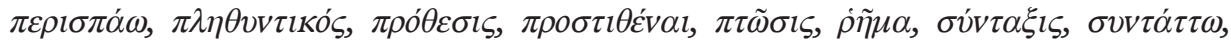

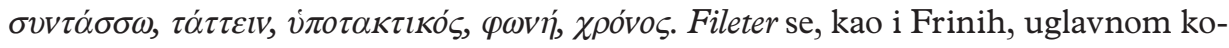
risti fonološkim i morfološkim nazivljem: nazivima za naglaske, vrste riječi, padeže, glagolska vremena, a od sintaktičkoga nazivlja upotrebljava glagole $\sigma v v \tau \alpha ́ \sigma \sigma \omega \mathrm{i}$ $\pi \rho o \sigma \tau \imath \theta \varepsilon ́ v \alpha \imath$ te imenicu $\sigma v ́ v \tau \alpha \xi_{\imath \varsigma}$. I kod njega je uočljiva sklonost uporabi priloga u nazivlju ( $\pi \alpha \rho o \xi v \tau o ́ v \omega \varsigma$; od naziva koji se ne poklapaju s Frinihom navodimo još priloge $\beta \alpha \rho v \tau o ́ v \omega \varsigma, \dot{\varepsilon} v \imath \kappa \tilde{\omega} \varsigma, \theta \eta \lambda v \kappa \tilde{\omega} \varsigma, \pi \alpha \rho \alpha \lambda o ́ \gamma \omega \varsigma, \pi \lambda \eta \theta v v \tau \imath \kappa \tilde{\omega} \varsigma)$. Iako Dain nije izdvojio

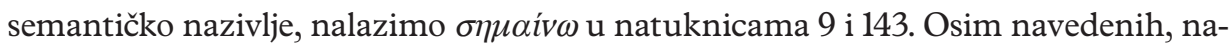
lazimo i nazive $\beta \alpha \rho v ́ \tau o v o \varsigma$ 'baritona' i $\beta \rho \alpha \chi \varepsilon \tilde{\imath} \alpha$ ' $k$ ratak (slog)' koji se odnose na izgovor i slogove te se i tu vidi sličnost s Frinihovim interesima.

\section{Zaključak}

Iz nazivlja navedenoga u prethodnim potpoglavljima možemo izvesti nekoliko zaključaka, ponajprije o Frinihovu poznavanju gramatičke teorije, a ne samo jezične prakse kojom se aticistički leksikografi u prvome redu bave. Za razliku od Antiaticista i Merida, čije su natuknice šturije od njegovih, Frinih se često koristi stručnim nazivljem. Frinih se u Izboru češće koristi nazivljem iz područja fonologije i morfologije, a rjeđe iz područja sintakse i semantike. Kod Frinihova su nazivlja među vrstama riječi koje upotrebljava česti prilozi, a rijetki pridjevi (osim ako nisu supstantivirani), dok se glagolima koristi kao stručnim nazivima za fonološki, sintaktički i semantički opis, ali ne morfološki (osim $\delta \imath \pi \lambda \alpha \sigma l \alpha ́ \zeta \omega)$. 
Nazivlje nije upotrebljavao sustavno. U fonologiji je, primjerice, više pozornosti posvećivao opisu izgovora, a manje elementima glasovnoga sustava, što je u skladu s njegovim interesom za jezičnu praksu, koju pokušava ispraviti. Najveći broj naziva odnosi se na fonologiju i morfologiju. Smatramo da je to zbog činjenice da Frinih reagira na jezične promjene u govornome jeziku, gdje su osobito uočljive bile promjene u izgovoru koje su utjecale i na morfologiju; općenito manje natuknica posvećuje sintaksi i semantici. Češću upotrebu fonološkoga i morfološkoga nazivlja objašnjavamo i dužom tradicijom toga nazivlja. Naposljetku, moguće je i pretpostaviti utjecaj stoičke škole za koju sintaksa, zajedno sa semantikom, nije pripadala istoj grani logike kao vrste riječi.

Nazivlje kojim se koristi može se povezati s grčkom jezikoslovnom tradicijom, osobito Dionizijem Tračaninom i Apolonijem Diskolom, te vrlo vjerojatno i Herodijanom - s obzirom na interes posvećen izgovoru, bilo bi logično da je poznavao rad stručnjaka za to područje koji mu je bio suvremenik. Što se tiče Dionizija Tračanina, ako prihvatimo tezu da je gramatika koja mu se pripisuje iz III. ili IV. st., dakle stoljeće-dva nakon Friniha, postavlja se pitanje tko je Frinihov izvor i je li možda on sam autor naziva za konjugacije ili umanjenice kojima se koristi. Druga je mogućnost da je Frinihov Izbor zapravo potvrda da je Gramatičko umijeće bilo poznato i općeprihvaćeno u njegovo doba. Tu mogućnost smatramo vjerojatnijom. Ako je Frinih želio pomoći suvremenicima da »ispravno« govore, logičnije je da se pritom koristio svima poznatim nazivljem umjesto da sam izmišlja nove nazive.

Iako se njime ne koristi sustavno, Frinih svakako pokazuje dobro poznavanje nazivlja, za razliku od autora djela Antiaticist i Merida, koji ga vrlo rijetko upotrebljavaju. Ovo istraživanje pokazuje da je Frinihu u uporabi nazivlja rječnik Fileter bliži od ostalih aticističkih rječnika. S Fileterom je, kako nagađa Fischer (Phrynichos 1974: 39-44), povezan i korištenjem istom građom te je ovaj rad dodatan dokaz njihove bliskosti. 


\section{LITERATURA}

Andriōtēs, Nikolaos (1995). Istoria tis ellēnikis glōssas. Aristoteleio Panepistēmio Thessalonikēs, Institouto Neoellēnikōn Spoudōn, [Idryma Manolē Triantaphyllidē], Thessalonikē. 2. pretisak 2005.

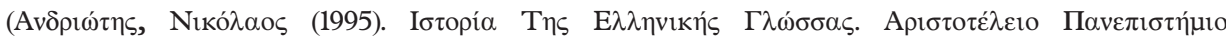

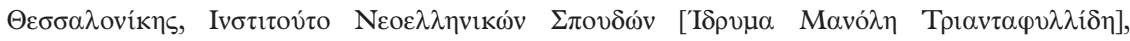

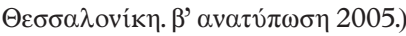

Apollonius Dyscole (1997). La syntaxe, volume II. Notes et index par Jean Lallot. Librairie philosophique J. Vrin, Paris.

Blanchard, Alain (1997). 'Destins de Ménandre'. Ktema 22, str. 213-225.

Blank, David i Catherine Atherton. The Stoic Contribution to Traditional Grammar. U: The Cambridge Companion to Stoics, ur. Brad Inwood. Cambridge University Press, Cambridge.

Browning, Robert (1983). Medieval and Modern Greek. Cambridge University Press, Cambridge. 2. izdanje.

Bubenik, Vit (2007). The Rise of Koine. U: A History of Ancient Greek: From the Beginnings to Late Antiquity, ur. A. F. Christidis. Cambridge University Press, Cambridge. 342-345.

Dain, Alphonse (1954). Le 'Philétaeros' attribué à Hérodien. Société d’édition 'Les belles lettres', Paris.

Dickey, Eleanor (2007). Ancient Greek Scholarship. Oxford University Press, Oxford.

Dionisio Tracio (2002). Gramática. Comentarios antiguos. Introducción, traducción y notas de Vicente Bécares Botas. Editorial Gredos, Madrid.

Dionizije Tračanin (1995). Gramatičko umijeće. Preveo i priredio Dubravko Škiljan. Latina et Graeca, Zagreb.

Horrocks, Geoffrey (2010). Greek: a History of the Language and its Speakers. Wiley-Blackwell, Chichester. 2. izdanje.

Householder, Fred W. (1981). The Syntax of Apollonius Dyscolus. Translated, and with commentary by Fred W. Householder. John Benjamins B. V., Amsterdam.

Ivić, Milka (2001). Pravci u lingvistici I. Biblioteka XX vek, Beograd.

Kazazis, John N. (2007). Atticism. U: A History of Ancient Greek: From the Beginnings to Late Antiquity, ur. A. F. Christidis. Cambridge University Press, Cambridge. 1200-1211.

Kotzia, Paraskevi (2007). Philosophical Vocabulary. U: A History of Ancient Greek: From the Beginnings to Late Antiquity, ur. A. F. Christidis. Cambridge University Press, Cambridge. 1089-1103.

Lee, John A. L. (2013). The Atticist Grammarians. U: The Language of the New Testament. Context, History and Development, ur. Stanley E. Porter i Andrew W. Pitts. Brill, Leiden i Boston. 283-308.

Matthews, Peter Hugoe (2007). The Ancient Grammarians. U: A History of Ancient Greek: From the Beginnings to Late Antiquity, ur. A. F. Christidis. Cambridge University Press, Cambridge. 1193-1199.

Missiou, Anna (2007). The Hellenistic Period. U: A History of Ancient Greek: From the Beginnings to Late Antiquity, ur. A. F. Christidis. Cambridge University Press, Cambridge. 323-341.

Moeris, Aelius (1998). Das attizistische Lexikon des Moeris: Quellenkritische Untersuchung und Edition. Herausgegeben von Dirk U. Hansen. Walter de Gruyter, Berlin i New York.

Phrynichos (1974). Die Ekloge des Phrynichos. Herausgegeben von Eitel Fischer. Walter de Gruyter, Berlin i New York.

Phrynichus Sophista (1911). Praeparatio sophistica. Edidit Joannes de Borries. B. G. Teubner, Leipzig.

Robins, Robert H. (1967). A Short History of Linguistics. Longman, London.

Strobel, Claudia (2005). The Lexicographer of the Second Sophistic as Collector of Words, Quotations and Knowledge. U: Selecta colligere, II, ur. Rosa Maria Piccione i Matthias Perkams. Edizioni dell’Orso, Alessandria. 131-157. 
Strobel, Claudia (2009). The Lexica of the Second Sophistic: Safeguarding Atticism. U: Standard Languages and Language Standards: Greek, Past and Present, ur. Alexandra Georgakopoulou I Michael Silk. Ashgate, Farnham. 93-107.

Swain, Simon (1996). Hellenism and Empire: Language, Classicism, and Power in the Greek World, AD 50-250. Clarendon Press, Oxford.

Škiljan, Dubravko, ur. (1996). Leksikon antičkih autora. Latina et Graeca i Matica hrvatska, Zagreb.

Valente, Stefano (2015). The Antiatticist: Introduction and Critical Edition. Walter de Gruyter, Berlin i Boston.

Vessella, Carlo (2018). Sophisticated Speakers: Atticistic Pronunciation in the Atticist Lexica. Walter de Gruyter, Berlin i Boston.

\title{
MREŽNI IZVORI
}

aticizam. http://www.enciklopedija.hr/Natuknica.aspx?ID=4427 (pristupljeno 4. 2. 2021)

Dionizije Tračanin. http://www.enciklopedija.hr/Natuknica.aspx?ID=15303 (pristupljeno 4. 2. 2021)

Grci. http://www.enciklopedija.hr/Natuknica.aspx?ID=23202 (pristupljeno 4. 2. 2021)

Gundulić, Ivan. https://www.enciklopedija.hr/Natuknica.aspx?ID=23793 (pristupljeno 4. 2. 2021)

koine. http://www.enciklopedija.hr/Natuknica.aspx?ID=32268 (pristupljeno 4. 2. 2021)

Logeion. https://logeion.uchicago.edu (pristupljeno 1. 2. 2021)

\section{LINGUISTIC TERMS IN PHRYNICHUS' ECLOGA}

\author{
Petra Matović \\ University of Zagreb, Faculty of Humanities and Social Sciences \\ pmatovic@ffzg.hr \\ Beata Kovačević \\ University of Zagreb, Faculty of Humanities and Social Sciences \\ beabeica94@gmail.com
}

ABSTRACT: The $2^{\text {nd }}$ century Atticist lexicographer Phrynichus was no stranger to linguistic terminology. His famous Ecloga includes many linguistic terms, mainly covering the areas of phonology and morphology. The number of syntax- and semantics-related terms is comparatively small. This is line with the development of the ancient Greek linguistic thought: the most influential ancient Greek grammar by Dionysius Thrax focused on phonology and morphology. Still, since Phrynichus was a near contemporary of Apollonius Dyscole, who wrote an extensive and influential treatise on syntax, it is somewhat surprising to find only the most basic syntactic vocabulary. Compared to other Atticist lexica, in his use of linguistic terms Phrynichus is closest to the Philetairos.

Keywords: Phrynichus; Greek lexicography; Atticism; Ancient Greek and Latin grammarians 